\title{
Terrorism and Human Rights
}

\author{
Saqib Jawad \\ International Islamic University, Pakistan \\ Civil Judge/Judicial Magistrate, Pakistan
}

Copyright (C) 2015 Horizon Research Publishing All rights reserved.

\begin{abstract}
Every human being is held entitled for human rights on the basis of simple characteristic of human being, and the same concept has also been recognized under the framework of international law in the shape of major human rights law instruments. Some of the human rights are even inalienable and non-derogable even in cases when some of them can be derogated under the need of the time. Terrorism being a great threat and violation of human rights is not disputed but protection of these rights during counter terrorism operations is also most relevant and requires discussion, because various abuses have been reported in the recent history regarding the violations of human rights during the conduct of counter terrorism operations and abuse of process on the pretext of counter terrorism measures. It has also been observed by the international bodies and organizations that the violations committed during counter terrorism operations are as much serious in nature as the acts of terrorism themselves and make no difference between the acts of terrorists and those who claim to be acting against them for elimination of the same. Some of the main reasons behind the violations of human rights are that the definition of terrorism itself has not been agreed upon among the states of the World claiming to be the eliminators of terrorism, and the same is due to the personal interests of the states and particularly the powerful states, because terrorists of one state or nation may be the heroes and freedom fighters of the other, and the freedom fighters of one may be the terrorists for the other one. On the basis of this reason, most of the times powerful states succeed to get control over the insurgents and use their own measures and parameters for the use of force, collateral damage, and principles of necessity which cause apprehension for the violations of human rights.
\end{abstract}

Keywords Counter Terrorism Measures, Derogation, Human Rights Committee , International Criminal Court , International Criminal Justice System , International Criminal Law, International Human Rights Law , International Humanitarian Law , Perpetrators, Terrorism, Violations

Case Law:

- $\quad$ PLD 2002 S. C. 841

- 2004 MLD 152.

\section{The Nature of Human Rights}

Human rights are generally defined as those rights which a person possesses by his simple characteristic of being a human. Moreover, these are those rights which are available to a person and protect his interests, freedom, dignity and other rights against the interference and excesses of states and their agents. Major human rights corpus included civil, political, cultural, economic, and social rights, and is universal in nature because these are available to all human beings 1 . In other words, human rights are inherent to all human beings, irrespective of nationality, race, sex or any other distinction2.

\section{International Human Rights Law}

In a technical definition, "International human rights law is a set of rules upon the basis of which certain groups or individuals may seek protection from their respective governments" 3 .

Universal Declaration of Human Rights (UDHR), is considered fundamental human rights document and binding on all states. International human rights law has been codified through major human rights treaties and the remaining portion is available in customary international law. The most important of these treaties are, International Covenant on Economic, Social and Cultural Rights; and the International Covenant on Civil and Political Rights, and its two Optional Protocols; International Convention on the Elimination of All Forms of Racial Discrimination; the Convention on the Elimination of All Forms of Discrimination against Women, and its Optional Protocol; the Convention against Torture and other Cruel, Inhuman or Degrading Treatment or Punishment, and its Optional Protocol; the Convention on the Rights of the Child, and its

\footnotetext{
1 Office of the United Nations High Commissioner for Human Rights Human Rights, Terrorism

and Counter-terrorism Fact Sheet No. 32, http://www.ohchr.org/Documents/Publications/Factsheet32EN.pdf,

accessed on 10-09-2011.

2 http://www.ohchr.org/en/issues/Pages/WhatareHumanRights.aspx, accessed on 12-09-2011.

3 International Humanitarian Law and International Human Rights Law: Similarities and differences,

http://www.ehl.icrc.org/images/resources/pdf/ihl_and_ihrl.pdf, accessed on 10-09-2011.
} 
two Optional Protocols; and the International Convention on the Protection of the Rights of All Migrant Workers and Members of Their Families. Two major human rights treaties has been concluded recently, namely the International Convention for the Protection of All Persons from Enforced Disappearance, and the Convention on the Rights of Persons with Disabilities and its Optional Protocol, which were all adopted in December 20064. Moreover, there are a number of other human rights treaties as well which are being concluded with the passage of time, because a large area of human rights till remains to be codified under the corpus of international human rights law.

Among these treaties, the part of Human rights which forms part of customary international law is considered to be binding on all states, whereas as far as other human rights treaties are concerned, only those states will be bound under those treaties which are party to it. Mechanism is also provided under international human rights law to enforce the obligations of states 5 .

\section{Terrorism}

Before going to determine the relation between terrorism and human rights, it seems necessary to define the terrorism itself. As far as the terrorism bill is concerned, section 1 of The British Terrorism Act 2000, defines the term as: "any action designed to influence the policy of any government, anywhere in the world, including by, for example, damage to property". This Bill was published on 12 October 2005, and before passing of the Bill, some draft clauses of the Bill were also consulted 6 .

Terrorism is generally understood as those acts of violence which spread terror among the civilians and civilian population. As far as the legal definition of terrorism is concerned, no comprehensive and exhaustive definition has yet been adopted by the international community having consensus upon it, but a number of international treaties and other international and regional instruments have included certain acts which amount to terrorism. In 1994, the General Assembly's Declaration on Measures to Eliminate International Terrorism, set out in its resolution 49/60, and stated that terrorism includes "criminal acts intended or calculated to provoke a state of terror in the general public, a group of persons or particular persons for political purposes"7.

It is constantly being emphasized to adopt a

4 Office of the United Nations High Commissioner for Human Rights Human Rights, Terrorism

and Counter-terrorism Fact Sheet No. 32,http://www.ohchr.org/Documents /Publications/Factsheet32EN.pdf, accessed on 10-09-2011.

5 Ibid.

6 Counter-Terrorism Policy and Human Rights: Terrorism Bill and related matters, House of Lords House of Commons Joint Committee on Human Rights, Third Report of Session 2005-06.

7 Office of the United Nations High Commissioner for Human Rights Human Rights, Terrorism

and Counter-terrorism Fact Sheet No. 32,http://www.ohchr.org/Documents /Publications/Factsheet32EN.pdf, accessed on 10-09-2011. comprehensive definition of terrorism and therefore a separate convention on terrorism is recommended to be adopted. In this regard, the General Assembly is currently working towards the adoption of a comprehensive convention against terrorism, which would complement the existing anti-terrorism conventions. Its draft Article 2, contains a definition of terrorism which includes "unlawfully and intentionally causing, attempting or threatening to cause" : " $(a)$ death or serious bodily injury to any person; or (b) serious damage to public or private property, including a place of public use, a State or government facility, a public transportation system, an infrastructure facility or the environment; or $(c)$ damage to property, places, facilities, or system, resulting or likely to result in major economic loss, when the purpose of the conduct, by its nature or context, is to intimidate a population, or to compel a Government or an international organization to do or abstain from doing any act8."

Moreover, the United States Department of Defense has defined the notion of terrorism that it is "the calculated use of unlawful violence or threat of unlawful violence to inculcate fear; intended to coerce or to intimidate governments or societies in the pursuit of goals that are generally political, religious, or ideological9."

\subsection{Is a global definition necessary or desirable?}

First issue in defining terrorism arises when it is questioned that, is a global definition of terrorism is desirable or not? Few states allege that if an exhaustive definition of terrorism is adopted, it will restrict the state capacity to take action in several cases against terrorism 10. Moreover, acts amounting to terrorism for a state may fall under the plea of self-defense for the other, and these issues are the main problem in defining the terrorism.

\subsection{What is a terrorist act?}

States have failed to frame any agreed and exhaustive definition of terrorism, although the term has been used at various occasions governing international law since 1937. After September 11, UN Security Council passed various resolutions regarding terrorism, and it was agreed that "states shall prevent and suppress the financing of terrorist acts" and shall take "necessary steps to prevent the commission of terrorist acts". But the term has not been defined neither in this resolution nor in any other document of the Security Council. Some of the acts have been included in terrorism by some of these documents, for instance Article 2(1) of the Draft of the United Nations on a Comprehensive Convention on International Terrorism provides that:-

(1) "Any person commits an offence within the meaning

\footnotetext{
8 Ibid.

9 International Terrorism and Security Research, http://www.terrorism-research.com/, accessed on 10-09-2011.

10 Talking about Terrorism - Risks and Choices for Human Rights Organizations 2008 International Council on Human Rights Policy, http://www.ichrp.org/files/reports/35/129_report_en.pdf
} 
of this Convention if that person, by any means, unlawfully and intentionally, causes:

(a) Death or serious bodily injury to any person; or

(b) Serious damage to public or private property, including a place of public use, a State or government facility, a public transportation system, an infrastructure facility or the environment; or

(c) Damage to property, places, facilities, or systems referred to in paragraph

1(b) of this article, resulting or likely to result in major economic loss, when the purpose of the conduct, by its nature or context, is to intimidate a population or to compel a Government or an international organization to do or abstain from doing an act" 11 .

A Terrorist Act has been defined in the following terms:-

"Terrorist Act - A person is said to commit a terrorist act if he, $(a)$ in order to, or if the effect of his actions will be to, strike terror or create a sense of fear and insecurity in the people, or any section of the people, does any act or thing by using bombs, dynamite or other explosive or inflammable substances, or such fire-arms or other lethal weapons as may be notified, or poisons or noxious gases or chemicals, in such a manner as to cause, or be likely to cause, the death of, or injury to, any person or persons, of the people; or damage to, or destruction of, property on a large scale, or a widespread disruption of supplies of services essential to the life of the community, or threatens with the use of force public servants in order to prevent them from discharging their lawful duties; or $(b)$ commits a scheduled offence, the effect of which will be, or be likely to be, to strike terror, or create a sense of fear and insecurity in the people, or any section of the people, or to adversely affect harmony among different sections of the people; or $(c)$ commits an act of gang rape, child molestation, or robbery coupled with rape as specified in the Schedule to this Act; or $(d)$ commits an act of civil commotion as specified in section 7A12.

\subsection{The impact of terrorism on human rights}

There is no doubt that terrorism is a great violation and threat to human rights. It violates all the provisions of all the international human rights and other instruments. Most importantly it directly deprives a person from the enjoyment of fundamental human rights, for instance right to life, which is the supreme human right as defined in the international convention on civil and political rights and other human rights instruments, freedom, and rule of law. Moreover it destabilizes the states and therefore anarchy and chaos spread in the society. Therefore all the states are obliged to protect these human rights of the individuals from every danger and protect them against the acts of terrorism by

11 Ibid.

12 Ibid. taking appropriate measures in this regard. Moreover in addressing the problem of terrorism states must distinguish between acts of terrorism and general criminal acts without which it is difficult to address the problem of terrorism and for that purpose it is desirable to define terrorism first 13 .

\subsection{Terrorism and international humanitarian law}

International Humanitarian Law (IHL), has been defined as the set of rules which is aimed to solve the problems, and protect the lives of the innocent people during an international or national/domestic armed conflict 14 . The fundamental goal of International humanitarian law (IHL) is to protect persons and their human rights in an armed conflict and reduce sufferings. IHL contains rules to be adopted during an armed conflict to achieve this end, which are contained in the four Geneva Conventions and their two Additional Protocols, as well as a number of other international instruments aimed at reducing human suffering in armed conflict. Some of these rules are now considered to be part of customary international law 15 .

\subsection{Terrorism and international criminal law}

In the last few years a number of conventions have been adopted to suppress the acts of terrorism, which have laid down many obligations upon the states to take appropriate measures in this regard and provide legal assistance in this regard working on the principle of aut dedere aut judicare or "extradite or prosecute" 16 . The relationship between human rights law and international criminal law is very much helpful in the enforcement of human rights, and a number of individuals including organizations and states have been prosecuted and punished for their alleged violations of international human rights and international humanitarian law.

\subsection{Terrorism and international refugee law}

International refugee law provides protection to the refugees who migrate from the effects of hostilities or on other basis set forth and defined in the refugee convention of 1951. States obligations have been determined in this regard which must be observed even during combat against terrorism 17.

13 Office of the United Nations High Commissioner for Human Rights Human Rights, Terrorism

and Counter-terrorism Fact Sheet No. 32,http://www.ohchr.org/Documents /Publications/Factsheet32EN.pdf, accessed on 10-09-2011.

14 International Humanitarian Law and International Human Rights Law: Similarities and differences, http://www.ehl.icrc.org/images/resources/pdf/i hl_and_ihrl.pdf, accessed on 10-09-2011.

15 Office of the United Nations High Commissioner for Human Rights Human Rights, Terrorism

and Counter-terrorism Fact Sheet No. 32,http://www.ohchr.org/Documents

/Publications/Factsheet32EN.pdf, accessed on 10-09-2011.

16 Ibid.

17 Ibid. 


\section{The Protection of Human Rights while Countering Terrorism}

The issue of terrorism has become more prominent particularly after September 11. Acts of terrorism and non state actors became a big threat for the World. But at times human rights and their protection becomes a big problem in facing as well as countering terrorism 18. As we have noticed that the acts of terrorism are injurious for the society, in the same way sometimes acts to combat terrorism become so. Under international law all the sates are bound to take effective measures against terrorism, but in doing so human rights of every society and individual must be protected in the best possible manner because both, taking effective measures against terrorism and protection of human rights are objectives of international and must not supersede each other 19.

\subsection{The central role of human rights and State obligations when countering terrorism}

After the adoption of the United Nations Global Counter-Terrorism Strategy by the General Assembly in its resolution 60/288 the World community has started adopting measures towards the protection of human rights in the fight against terrorism. They have pledged to ensure that all the measures being taken in the fight against terrorism are in accordance with their general obligations under international law. This was further discussed in the World Summit Outcome, adopted by the General Assembly in 2005, and respect of human rights during fight against terrorism was emphasized, and particularly human rights relevant to refugee law, international criminal law and international humanitarian law20.

At the domestic level one may criticize the other states, but at the international level it is rarely seen that human rights abuses committed by a state outside its own territory are criticized or noticed by the international community. But in the present scenario certain rules have been developed under which concept of state responsibility has been realized 21. At various occasions Security Council also criticized states on promoting terrorism 22. Moreover

18 Wilder Tayler, Notes on the Human Rights Movement and the Issue of Terrorism, International Council on Human Rights Policy, 2005, http://www.ichrp.org/files/papers/78/129_-_Notes_on the_Human_Rights Movement and the Issue of Terrorism $\overline{\text { Tayler }}{ }^{-}$Wilder $\overline{-}$ 2005.pdf, accessed on $\overline{2} 5-0 \overline{9}-20 \overline{1} 1$.

19 Office of the United Nations High Commissioner for Human Rights Human Rights, Terrorism

and Counter-terrorism Fact Sheet No. 32,

http://www.ohchr.org/Documents/Publications/Factsheet32EN.pdf, accessed on 10-09-2011. 20 Ibid.

21 Mark Gibney, Katarina Tomaševski, Jens Vedsted-Hansen, Transnational State Responsibility for Violations of Human Rights, Harvard Human Rights Journal,http://www.law.harvard.edu/students/orgs/hrj/iss12/ gibney.shtml, accessed on 13-09-2011.

22 Wilder Tayler, Notes on the Human Rights Movement and the Issue of Terrorism, International Council on Human Rights Policy, 2005, http://www.ichrp.org/files/papers/78/129_-_Notes_on the_Human_Rights Movement and the Issue of Terrorism_ Tayler_Wilder ${ }_{-}{ }_{-}$2005.pdf, accessed on $\overline{2} 5-0 \overline{9}-20 \overline{1} 1$. recently at times action has been taken against various states, organizations, and even individuals who were alleged to have violated human rights.

\subsection{The flexibility of human rights law}

After September 11, although the USA has taken steps against terrorism, but the USA administration failed to understand that in what manner international law can be applied to the situation 23. Therefore on the one hand where to fight terrorism is an obligation under international law in the same way respect and to ensure of the protection of human rights is also an equal obligation of the states under international human rights law24.

\subsection{Limitations}

However keeping in view the circumstances of the case and all the international human rights instruments, states can limit certain human rights for a specific time period. For instance right to freedom of expression, the right to freedom of association and assembly, the right to freedom of movement, and the right to respect for one's private and family life, but in doing so every state should observe a number of conditions, in order to restrict abuse of this authority 25 .

\section{Prescription by Law}

The concept shows that while putting limits on the enjoyment of human rights by the regional or domestic human rights instruments it should be made clear that what are the parameters of these limitations, so that every individual will be able to have recourse to the appropriate legal remedy and the citizens should regulate their conduct accordingly 26. In accordance with this concept right to due process of law is recognized as a fundamental right of every person, as Article 4 of the Constitution of Pakistan stipulates this right for every person.

\subsection{In the pursuance of a legitimate purpose}

The United Nations human rights committee also noted that the list enumerating non derogable rights was not exhaustive, rather in addition to the rights mentioned therein there were also other rights which cannot be derogated27. The permissible and legitimate restrictions and limitations on the enjoyment of fundamental human

\footnotetext{
23 Terrorism and international law: Challenges and responses, http://www.iihl.org/iihl/Album/terrorism-law.pdf, accessed on 25-09-2011. 24 Office of the United Nations High Commissioner for Human Rights Human Rights, Terrorism

and Counter-terrorism Fact Sheet No. 32,http://www.ohchr.org/Documents /Publications/Factsheet32EN.pdf, accessed on 10-09-2011.

25 Ibid.

26 Ibid.

27 Terrorism and international law: Challenges and responses, http://www.iihl.org/iihl/Album/terrorism-law.pdf, accessed on 25-09-2011.
} 
rights will vary according to the need and circumstances of the time. Usually the main grounds for these limitations are national security, public safety, public order, health, morals, and the human rights and freedoms of others 28 .

\subsection{Necessity and proportionality}

These two principles are of fundamental nature regarding the limitations on the human rights, and they must be tested on real basis, and the objective for that purpose must be of a pressing nature of the need. Moreover the principle of proportionality must be kept intact and the limitations should be proportional according to the necessity. Freedom of expression is a recognized human right, but if such a right is being used for the purposes of incitement and promotion of terrorism, then the enjoyment of this particular human right norm may be restricted but that too should be in accordance with the prescription of law, for a legitimate purpose, and should be necessary and proportional 29 .

\subsection{Derogations}

Although certain treaties provide the mechanism of the derogation of human rights but they have also put restrictions and limitations for doing so30. In the state of emergency and other such like situations, it is made permissible under international law to derogate for certain human rights. This principle has been laid down in Article 4 of international covenant on civil and political rights, (ICCPR). But it has also been laid down that the requirements to exercise such a right by a state should also be fulfilled in accordance with other provisions of the covenant, and states must comply with their general international law obligations 31 .

\subsection{Non-derogable human rights}

The criteria for the derogation of these rights has been prescribed that a situation of public emergency should exist, otherwise derogation of human rights will not be a permissible act32. On the other hand under Article 4(2) of the ICCPR, certain human rights have been brought under

\footnotetext{
28 Office of the United Nations High Commissioner for Human Rights Human Rights, Terrorism

and Counter-terrorism Fact Sheet No. 32,

http://www.ohchr.org/Documents/Publications/Factsheet32EN.pdf, accessed on 10-09-2011.

29 Ibid.

30 Derogation from human rights treaties in situations of emergency, Rule of law in Armed Conflicts, Project, http://www.adh-geneva.ch/RULAC/der ogation_from_human_rights_treaties_in_situations_of_emergency.php, accesse $\bar{d}$ on $0 \overline{2}-10-20 \overline{1} 1$.

31 Office of the United Nations High Commissioner for Human Rights Human Rights, Terrorism

and Counter-terrorism Fact Sheet No. 32,http://www.ohchr.org/Documents /Publications/Factsheet32EN.pdf, accessed on 10-09-2011.
}

32 Derogation from human rights treaties in situations of emergency, Rule of law in Armed Conflicts, Project, http://www.adh-geneva.ch/RULAC/der ogation_from human rights_treaties_in_situations_of_emergency.php, accesse $\bar{d}$ on $0 \overline{2}-10-20 \overline{1} 1$. the category of non derogable rights, which means that even in emergency and such like situations the rights mentioned in this category cannot be derogated. These rights are, the right to life, freedom from torture or cruel, inhuman or degrading treatment or punishment, the prohibition against slavery and servitude, freedom from imprisonment for failure to fulfill a contract, freedom from retrospective penalties, the right to be recognized as a person before the law, and freedom of thought, conscience and religion 33 .

\subsection{Permissible extent of derogations}

It is allege that the derogation of human rights is a rational response and states can use it while facing serious threats 34 . Moreover even the power of a state to derogate from certain human rights norm under Article 4(1) of the covenant is not unlimited, but there is a permissible extent for such exercise of derogation. Hence derogations under the Article must be temporary in nature and the ultimate objective of the state should be to restore the situation of normalcy as soon as possible35.

\section{Specific Human Rights Challenges in the Context of Terrorism}

\subsection{The right to life}

It is alleged that human rights violations are committed by different groups and non state actors during terrorism, but states are also seen involved in the commission of the violations of human rights, and that is primarily based on lack of accountability and transparency36. Right to life is a fundamental human right, in absence of which one will not be able t enjoy any further human right. In counter terrorism policy although states are obliged to take appropriate measures against terrorism but they have endangered the life of citizens, especially with regard to targeted killings as alternative to their arrest and trials. Carpet bombing and targeted bombing is also a practice which has been adopted by the states on the pretext of countering terrorism, as the former has been witnessed in tribal areas by Pakistani armed forces, and the later has been seen in the shape of drone attacks by the USA37.

33 Office of the United Nations High Commissioner for Human Rights Human Rights, Terrorism

and Counter-terrorism Fact Sheet No. 32,http://www.ohchr.org/Documents /Publications/Factsheet32EN.pdf, accessed on 10-09-2011.

34 Emilie Marie Hafner-Burton, Laurence R. Helfer, Christopher J. Fariss, Emergency and Escape: Explaining Derogation from Human Rights Treaties, http://papers.ssrn.com/sol3/papers.cfm?abstract_id=1622732, accessed on 10-10-2011.

35 Office of the United Nations High Commissioner for Human Rights Human Rights, Terrorism

and Counter-terrorism Fact Sheet No. 32,http://www.ohchr.org/Documents /Publications/Factsheet32EN.pdf, accessed on 10-09-2011.

36 Wilson John and P.V. Ramana, Terrorism and Human Rights, http://www.observerindia.com/cms/export/orfonline/modules/policybrief/at tachments/trs 1171547246121.pdf, accessed on 10-10-2011.

37 Office of the United Nations High Commissioner for Human Rights 


\subsection{Challenges to the absolute prohibition against torture}

Torture is a serious human rights violation under the international law, and has been defined in Article 1 of the In the Convention against Torture and Other Cruel, Inhuman or Degrading Treatment or Punishment38, The prohibition of torture and other cruel, inhuman or degrading treatment or punishment is a norm of customary international law, and a rule of jus cogens hence is a binding norm of international law. Convention against torture strictly prohibits such a like practice by the states and especially with regard to extracting information or confessional statements by the suspects, which has often been noted being committed by the states who claim that they are fighting terrorism 39.

\subsection{Transfer of individuals suspected of terrorist activity}

All the suspects of terrorism should be dealt with in accordance with the provisions of international law, and no detention, arrest, or transfer of suspects should be based without due process of law. But unfortunately especially after 9-11, the practice of the states goes against these principles. Suspects of terrorists were extradited, transferred and deported even some of them were asylum seekers. All this was done in vilation of the principle of non refoulment which is said by the jurists as a principle of jus cogens. Moreover forced disappearance is also prohibited under Article 16 of the International Convention for the Protection of All Persons from Enforced Disappearance, and also recognized in article 7 of the International Covenant on Civil and Political Rights 40.

Not only this rather some of the diplomats were not protected in this process. Example of Abdul Salam Zaeef, Afghan ambassador in Pakistan is one of these.

\subsection{Liberty and security of the person}

Some states have introduced new provisions in their criminal law procedure to effectively counter terrorism, but these steps may be in violation of worldly recognized norms of human rights and without due process of law. These provisions include inclusion of provisions regarding the bail, remand and arrest of these suspects. For instance, pretrial detention which cane be effected before any specific charge, administrative detention, to prevent a person from committing or associating in commission of any offence, control orders, to control a situation while keeping a person in detention, and compulsory hearings, which allows

Human Rights, Terrorism

and Counter-terrorism Fact Sheet No. 32,http://www.ohchr.org/Documents /Publications/Factsheet32EN.pdf, accessed on 10-09-2011.

38 Torture, Inhuman or Degrading Treatment, http://www.hrea.org/index.p hp?doc id=265, accessed on 10-10-2011.

39 Office of the United Nations High Commissioner for Human Rights Human Rights, Terrorism

and Counter-terrorism Fact Sheet No. 32,http://www.ohchr.org/Documents /Publications/Factsheet32EN.pdf, accessed on 10-09-2011.

40 Ibid. authorities compulsory questioning and gathering information from the suspects may be cited in this context 41 .

\section{State Violations}

Human rights violations are committed by the states in various situations. For instance, during search operations, encounters, which are some times genuine and at other times fake, especially with regard to Pakistan Police, opening fire in crowded areas, during detention and interrogation even if the accused has been detained without following any legal order. These violations of human rights result for a number of reasons, for instance, lack of transparency and accountability, inadequate training and education among security personnel in observing human rights, lack of scientific investigation skills and tools among the police, deficient information to, and investigation by, the police, and a moribund judicial system. Some times people raise their voice on these violations being committed as state terrorism. For instance the Supreme Court of India noted in D.K. Basu vs. state of West Bengal that: "State terrorism is no answer to combat terrorism" 42 .

Moreover, unfortunately, even after Independence, our army and police are trained on colonial footings, and that is the main reason behind their violations of human rights and state terrorism 43 .

\section{The "war on terror" focused human rights issues}

The issues of 9-11 attacks, the subsequent pronouncement of crusade or the war on terror, and the development of counter terrorism efforts have long standing effects on both human rights and terrorism. According to Human Rights Watch, the countries which intended to use counter terrorism policy to adopt punitive measures and persecute their political opponents are: Australia, Belarus, China, Egypt, Eritrea, India, Israel, Jordan, Kyrgyzstan, Liberia, Macedonia, Malaysia, Russia, Syria, the United States, Uzbekistan and Zimbabwe44.

\section{The Historical Response of Human Rights Groups}

Historically, the way that human rights organizations dealt with violence committed by armed groups reflected the central importance of international human rights law to their work. Because these standards apply primarily to the powers and obligations of states, the behaviour of armed non-governmental groups was considered to fall outside the scope and authority of human rights monitoring; since non-state actors do not ratify international human rights

41 Ibid.

42 Wilson John and P.V. Ramana, Terrorism and Human Rights, ORF policy brief, February 2007.

43 Ibid..

44 Amy Zalman, Human Rights \& Terrorism: An Overview Expanding anti-terror measures produces new human rights issues, http://terrorism.about.com/od/humanrights/a/Human_Rights.htm 
treaties, they could not be held responsible for implementing them 45 .

For many years, Amnesty International therefore took the view that "abuses" by armed groups (then called "non-governmental entities") should be distinguished from "violations" of human rights by government. Until 1991 the organization did not conduct research or campaigning activities on abuses by non-governmental entities. In that year, Amnesty International's sovereign body, the International Council Meeting, changed this long-standing position, recognizing "the seriousness of the human suffering caused by acts against individuals, in contravention of fundamental standards of humane behavior, that are perpetrated by political non-governmental entities". The starting point of this change was clearly the perspective and rights of victims. The same decision clarified that Amnesty International "should continue to regard human rights as the individual's rights in relation to governmental authority". As Amnesty International and Human Rights Watch (and scholars) have struggled with this issue, concerted attempts have been made to define the position of non-state actors within international human rights law. At the same time, human rights groups, both international and domestic, have repeatedly grappled with acutely difficult situations involving terrorist violence. A consistent approach is hardly any closer, although the scholarly consensus is definitely shifting towards a view that states are no longer the sole subjects of international law46.

\section{Profiling and the Principle of Non-discrimination}

Principle of equality before the law and non-discrimination is one of the fundamental principles of international law and every legal system. Article 2, paragraph 1, of the International Covenant on Civil and Political Rights lays down that every state party has to observe this principle with regard to any person present at its territory and jurisdiction47. But as we have noted earlier by introduction of a discriminatory legal procedure to these terrorism suspects violates this fundamental principle. Human rights committee in this context has revised its general comment on Article 14 of ICCPR, in 207, and has added that right to fair trial and equality before the law is the key element in the enjoyment of international human rights 48 .

45 Talking about Terrorism - Risks and Choices for Human Rights Organisations, International Council on Human Rights Policy, (2008), http://www.ichrp.org/files/reports/35/129_report_en.pdf, accessed on 24-09-2011.

46 Ibid.

47 General Comment No. 18: Non-discrimination : . 11/10/1989.

CCPR General Comment No. 18. (General Comments) http://www.unhchr.ch/tbs/doc.nsf/0/3888b0541f8501c9c12563ed004b8d0e ?Opendocument, accessed on 12-10-2011.

48 Office of the United Nations High Commissioner for Human Rights Human Rights, Terrorism

and Counter-terrorism Fact Sheet No. 32,http://www.ohchr.org/Documents

\subsection{Surveillance, data protection and the right to privacy}

According to Article 17 ICCPR, unlawful and arbitrary interference in the privacy of certain individuals is prohibited under international law. But this has been practice which continues with regard to suspects of terrorism which not only violates their individual right to privacy for the purpose of collection of data and other information, rather in some cases their family members and homes are not protected 49 .

Suicide attacks are considered as grave violations of human rights, and the perpetrators are considered war criminals, because in committing these acts they are alleged to have committed crimes against humanity 50 . Suicide bombing is another important issue in combating terrorism. Suicide attacks became effective in the present day armed conflict on the ground that they are being launched easily as compared to any other attack. For instance it is more easy for a perpetrator to launch an attack while driving a truck and exploding it in any area then to explode it by direct attack or through remote control devices. But on the other hand where suicide attacks are a big threat for the community in the same way humanity is bearing a big loss in combating it. In Iraq many people have been shot on the assumption that they were suicide bombers, but were later on revealed as innocent citizens. In 2005, a Brazilian was shot in London by the Police on the same assumption51.

On the other hand, all the major groups who are behind suicide bombings are doing so on the ground of national interest or self-determination. For instance Palestinians against Israel, Al- Qaeda, Hizb'allah, Chechens, and even the Tigers of Tamil Eelam (LTTE) in Sri Lanka, are conducting these activities on the same grounds, which can be negotiated and resolved through peaceful means if the other parties are willing to do so and save themselves from these attacks 52 .

Currently, suicide bombing is the aspect of terrorism that tends to arouse greatest public concern. This is partly because it is so difficult to combat. Suicide bombing undoubtedly brings another dimension to terrorist attacks. Past security measures have been premised on the assumption that terrorists will wish to escape alive (hence procedures such as matching airline passengers with their hold baggage). Suicide bombing is effective because it evades such measures. Attacks are often technically simpler as well: truck bombs of the kind that have killed thousands of people in Iraq can be exploded more easily if they are steered and detonated by a human driver. The fear they inspire, as well as the technical difficulties of combating them, often lead security agencies to overreact. In Iraq and other

/Publications/Factsheet32EN.pdf, accessed on 10-09-2011.

49 Ibid.

50 Human Rights Watch: Suicide bombers 'war criminals', accessed on 12-10-2011.

51 Ibid.

52 Talking about Terrorism - Risks and Choices for Human Rights Organisations, International Council on Human Rights Policy, (2008), http://www.ichrp.org/files/reports/35/129 report en.pdf, accessed on 24-09-2011. 
conflicts, many individuals have been shot in their vehicles because they have been mistaken for suicide bombers; in an infamous incident in London in 2005 a Brazilian was shot dead by police on the London Underground for the same reason53.

Many of the groups that have used suicide bombers including Hizb'allah in Lebanon, Hamas in Palestine, the Liberation Tigers of Tamil Eelam (LTTE) in Sri Lanka, various Chechen national groups, different Iraqi factions have had the rational and often realisable goal of securing national self-determination. Pape argues that even al-Qaeda fits this pattern on the grounds that two of its stated demands were the expulsion of United States (US) troops from the Arabian Peninsula and of Israeli troops from Jerusalem. Both these aims are technically realizable (could be the subject of negotiation) and command political support54.

\subsection{State terrorism}

On the other hand at times terrorism may be committed on the part of states instead of individuals or individual groups. That form of terrorism may be in the shape of extrajudicial killings enforced disappearance, torture and so on. The term was used particularly when French government agents blew Rainbow warrior in 1985, and presently various human rights organizations are using the term frequently in Latin America and Middle East.

Violations of the United States have been reported 55. Later on other states also practiced the same in the so called war on terror 56. The detainees of Guantanamo are the biggest example, how the prisoners can be prevented from their recourse to international and domestic law. The situation is described by The English Court of Appeal as a "legal black hole". "If you want a definition of this place, you don't have the right to have rights", wrote Nizar Sassi, a French detainee, on a postcard addressed to his family 57. But in June, 2004, the U.S. Supreme Court setting aside the previous ruling about the Guantanamo Bay detainees ruled in Rasul v. Bush that U.S. courts have jurisdiction to hear the petitions of habeas corpus filed by the detainees of war on terrorism, at the U.S. Naval Station in Guantanamo Bay, Cuba58.

\section{International Humanitarian Law (IHL)}

\footnotetext{
53 Ibid.

54 Ibid.

55 Accountability for US counter-terrorism human rights violations 56 The Berlin Declaration, The ICJ Declaration on Upholding Human Rights and the Rule of Law in Combating Terrorism Adopted 28 August 2004

57 August 2008 Combating Terrorism under Human Rights and Humanitarian Law Regime Dr. Borhan Uddin Khan, Muhammad Mahbubur Rahman

58 CRS Report for Congress Received through the CRS Web Order Code RL31367 Treatment of "Battlefield Detainees" in the War on Terrorism Updated November 15, 2005.
}

International humanitarian law (IHL) becomes relevant at the time of armed conflict, and includes Four Geneva Conventions, their two Additional Protocols, and the relevant portion of customary international law. Although IHL at times allows to take the life of enemy combatants, but principle of distinction, being fundamental principle of IHL has to be fully kept intact while doing so59.

\subsection{International criminal law}

International criminal law has provided mechanism for the responsibility of war criminals and perpetrators of grave breaches of international law. Ad hic tribunals have been established to prosecute these criminals, and examples are international criminal tribunal for Yugoslavia and Rwanda. On the other hand international criminal law has provided that states may enter into treaties that provide jurisdiction and procedure to prosecute these criminals. Thirdly some states have promulgated certain rules in their national legislation, as Belgian law provided but was unfortunately amended later on due to the pressure of USA. Rome statute of international criminal court is also a big development in international criminal law, which became enforced in 2002, and Article 5 of the Rome Statute provides that international criminal court has jurisdiction on the following crimes:-

Genocide (as defined in Article 6),

Crimes against humanity (as defined in Article 7), and

War crimes (as defined in Article 8).

Crime of aggression 60 .

\section{International Human Rights Law}

Human rights law deals with every kind of human rights and is concerned with human beings, and protects their rights, whether he or she is a criminal, terrorist or an innocent human being 61 .

On the other hand at times states have agreed that that they should take measures to combat terrorism in accordance with their obligations under the international law, international human rights law, and humanitarian law on the ground that combating terrorism and protection of human rights is not in conflict to each other. It has been agreed that there are some non negotiable rights which shall be protected at any cost, for instance prohibition of torture and other inhuman and degrading treatment or punishment. Secret detention and rendition is consistent neither with international humanitarian law, nor with international human rights law, on the ground that it will increase the risk of torture and other degrading and inhuman treatment 62.

\footnotetext{
59 Ibid.

60 Ibid.

61 Talking about Terrorism - Risks and Choices for Human Rights Organizations 2008 International Council on Human Rights Policy, http://www.ichrp.org/files/reports/35/129_report_en.pdf

62 Euro-Mediterranean Seminar Counter-terrorism and human rights Prague (16-17 June) http://www.consilium.europa.eu/uedocs/cmsUpload/s peech-Counter-terrorism_and_human_rights_GdK_june_08_rev.pdf
} 
Counter-Terrorism Committee (CTC) was established in 2001, and by the Security Council resolution 1456 (2003), and by other resolutions as well it was laid down that all steps in combating terrorism should be taken by all states in accordance with their other obligations under international law. It was provided in Security Council resolution 1373 (2001), which established the CTC, that states are obliged to:-

"take appropriate measures in conformity with the relevant provisions of national and international law, including international standards of human rights, before granting refugee status, for the purpose of ensuring that the asylum seeker has not planned, facilitated or participated in the commission of terrorist acts."

\subsection{A pro-active approach:-}

Another step was taken that Counter-Terrorism Committee Executive Directorate (CTED) was established by the Security Council resolution 1535 (2004), t work with UN High Commissioner for Human Rights (OHCHR) and other human rights organizations and was tasked to take appropriate measures for the protection of human rights in combating terrorism. Later on CTED adopted its plicy guidelines and it was provided that CTED is mandated to:-

- "Provide advice to the Committee, including for its ongoing dialogue with States on their implementation of resolution 1373 (2001), on international human rights, refugee and humanitarian law, in connection with identification and implementation of effective measures to implement resolution 1373 (2001)

- Advise the Committee on how to ensure that any measures States take to implement the provisions of resolution 1624 (2005) comply with their obligations under international law, in particular international human rights law, refugee law, and humanitarian law; and

- Liaise with the Office of the High Commissioner for Human Rights and, as appropriate, with other human rights organizations in matters related to counter-terrorism" 63 .

No doubt every act of terrorism restricts rights of the people, but on the other hand every act in counter terrorism policy may restrict the human rights of the people 64. So policy guidelines should be adopted which protect people from terrorism without any further violation of their universally recognized human rights standards.

At international level there are two schools of thought regarding the strategy employed by them to counter terrorism. On the one hand British school considers it a crime, and adopts measures to control it through local enforcement

63 Protecting human Rights While Countering Terrorism, http://www.un.org/en/sc/ctc/rights.html

64 Y.P. Chhibbar, Terrorism and Human Rights: National and International Perspective, PUCL Bulletin, 2003, http://www.pucl.org/Topics/Human-rig hts/2003/terrorism.htm agencies such as Police in cooperation with other international organizations. On the other hand American school considers terrorism a war or threat of war and allows military use of force and other measures to combat 65 .

\section{Pakistan Perspective}

The main focus of the World towards terrorism was developed after the attacks on World Trade Centre twin towers and Pentagon on September11, 2001. Since first time in the history the USA has witnessed such like attacks and every citizen of the U S A felt humiliated as no way was there even to defend themselves.

It is fact that every act of terrorism infringes certain human rights in the other way66.

Pakistan is also fighting its war against terrorism, and in the same manner huge violations have been committed during this war.

Anti-Terrorism Act, was adopted by Pakistan in 1997. And the purpose of the act was to suppress the acts of terrorism and provide speedy trials for the like cases. On 31 January 2002, which was specifically intended to include military officers in the judicial system for the purpose of trying the cases of terrorism, which was an attack on the independence of judiciary. New courts were established by the ordinance which included one senior military officer and two civil judicial officers, and the function of the court was to sit in military cantonments and jails and try such cases 67 .

General penal law in Pakistan regulating and defining the crimes committed is the Pakistan Penal Code of 1860, and the same was enforced in Pakistan soon after independence. However, with the passage of time it was felt that a special law with regard to terrorism needs to be enacted for speedy and expeditious disposal of the crimes of heinous nature, and accordingly the Anti-Terrorism Act 1997 was promulgated. It was held by the August Supreme Court of Pakistan that the Anti-Terrorism Act 1997 was brought into force for the prevention of terrorism, sectarian violence and for speedy trial of heinous offences for matters connected therewith and incidental thereto 68 .

In this regard it is necessary to have a look at the definition of terrorism provided in the Act. The definition is provided under section 6 of the Act in the following manner:-

In this Act. "terrorism" means the use or threat of action where:

(a) The action falls with the meaning of sub-section (2). And

(b) The use or threat is designed to coerce and intimidate

65Terrorism And Human Rights: Role Of The Security Personnel And The Police,

http://www.legalserviceindia.com/article/1271-Terrorism-And-Human-Righ ts.html

66 Y.P. Chhibbar, Terrorism and Human Rights: National and International Perspective, http://www.pucl.org/Topics/Human-rights/2003/terrorism.htm 67Lellie Ortega, Anti-terrorist laws in Pakistan, http://www.india-seminar. com/2002/512/512\%20kellie\%20ortega.htm, accessed on 20-10-2011.

68 PLD 2002 S. C. 841. 
or overawe the Government or the public or a section of the public or community or sect or create a sense of fear or insecurity in society; or

(c) The use or threat is made for the purpose of advancing a religious, sectarian or ethnic cause.

2) An "action" shall fall within the meaning of sub-section(1), if it:

(a) Involves the doing or anything that causes death;

(b) Involves grievous violence against a person or grievous body injury or harm to person;

(c) Involves grievous damage to property:

(d) Involves the doing of anything that is likely to cause death or endangers a person's life;

(e) Involves kidnapping for ransom, hostage-taking or hijacking;

(f) Incites hatred and contempt on religious, sectarian or ethnic basis to stir violence or cause internal disturbance;

(g) Involve stoning, brick-batting or any other from of mischief to spread panic:

(h) Involves firing on religious congregations, mosques, imambargahs, churches, temples and all other places of worship, or random firing to spread panic, or involves any forcible takeover o mosques or other places of worship;

(i) Creates a serious risk to safety of public Or a section of the public, or is designed to frighten the general public and thereby prevent them from coming out and carry8ing on their lawful trade and daily business, and disrupts civil (civic) life;

(j) Involves the burning of vehicles or an other serious form of arson;

(k) Involves extortion of money (bhatta) or property;

(l) Is designed to seriously interfere with or seriously disrupt a communications system or public utility service;

(m) Involves serious coercion or intimidation of a public servant in order to force him to discharge or to refrain from discharging his lawful duties; or

(n) Involves serious violence against a member of the police force, armed forces, civil armed forces, or a public servant.

Besides the above said circumstances under subsection 3 of section 6 of the Act it has also been provided that:-

The use or threat or use of any action falling within sub-section (2) which involves the use of fire-arms, explosives or any other weapon, is terrorism, whether or not subsection 1 (c) is satisfied.

The Act received the assent of the President of Pakistan on $16^{\text {th }}$ August 1997, and came into force at once. The question may arise under what law the offences of the same category committed prior to the enforcement of the Act shall be regulated. In this regard separate provision in the shape of section 38 of the Act has been provided which states that:-

Where a person has committed an offence before the commencement of this Act which if committed after the date on which $\mathrm{h}$ this Act comes into force would constitute a terrorist act hereunder he shall be tried under this Act but shall be liable to punishment as authorized by law at the time the offence was committed.

Under section 8 of the Act, acts intended or likely to stir up sectarian hatred have also been declared an offence in the following manner:-

A person

who:-

(a) uses threatening, abusive or insulting words or behavior; or

(b) displays, publishes or distributes any written material which is threatening, abusive or insulting: or words or behavior; or

(c) distributes or shows or plays a recording or visual images or sounds which are threatening, abusive or insulting: or

(d) has in his possession written material or a recording or visual images or sounds which are threatening, abusive or insulting with a view to their being displayed or published by himself or another, Shall be guilty of an offence if:--

i. he intends thereby to stir up sectarian hatred; or

ii. having regard to all the circumstances, sectarian hatred is likely to be stirred up thereby.

However, as contained above, intention is necessary to constitute an offence and circumstances in which the sectarian hatred is likely to be caused have also not been narrated. It has also been held that mere possession of audio cassettes and books is not enough to constitute an offence under section 8 of the Act 69 .

Besides individuals, organizations have also been made subject matter of the Act. Under section 11-A of the Act, cases have been provided under which an organization is said to have been concern in terrorism if:-

a. Commits or participates in acts of terrorism;

b. Prepares for terrorism;

c. Promotes of encourages terrorism;

d. Supports and assists any organization concerned with terrorism;

e. Patronize and assists in the incitement of hatred and contempt on religious sectarian or ethnic lines that stir up disorder;

f. Fails to expel from its ranks or ostracize those who commit acts of terrorism and present them as heroic persons:- or

g. Is otherwise concerned in terrorism.

Moreover, under section 11-B of the Act, organizations concerned in the acts of terrorism can be proscribed.

Although, detailed provisions have been contained in this Act, but still dire need was felt to introduce a new law or amend the existing one in order to cope with the vulnerable society after occurrence of the events particularly after the start of war against terrorism. So in continuation with this

692004 MLD 152. 
thought another law over the subject has been promulgated namely Protection of Pakistan Ordinance 2013 which has recently been converted into the Protection of Pakistan Act 2014.

After promulgation of the Ordinance, amendments were brought in the year 2014, and in the same year the bill was passed from the National Assembly as well as Senate and became an Act on 14.07.2014.

A key characteristic of the Act is that a separate schedule has been given in the same specifying the offences (scheduled offences), for special jurisdiction under the Act special court is to be created for trial and a special judicial magistrate for grant of physical custody of the accused which may be extended up to ninety days.

But apart from the other aspects, the Act excludes the application of certain provisions of the ordinary law particularly provisions of the Criminal Procedure Code dealing with the grant of bail, acquittal, appeal and revision. The legal analysis of these aspects can be analyzed deeply in a separate study because most of the excluded provisions are prejudicial over the rights of the accused. For the same purpose observations have been made by Human Rights Activists as well as such like national and international bodies.

The main observation in view is that the Act is primarily intended to fulfill the gaps and lacunas which were being faced by the security agencies for the detention of the suspects. All the excluded provisions of the Criminal Procedure Code deal with the rights of accused which may be exercised by him where no incriminating evidence is available against the accused and where the allegation levelled is baseless. But the application of these provisions including bail and acquittal are specifically been excluded from the jurisdiction of the court meaning thereby that even if the accused found innocent by the court during his trial he cannot be left after acceptance of bail and in the shape of his acquittal. In other words, the unlawful detentions without due process are intended to be made lawful through this Act. Hence, for the foregoing reasons the Ordinance appears to be against the spirit of the Fundamental rights guaranteed under the Constitution of Islamic Republic of Pakistan including the due process of law and the right of fair trial as well as against the Human rights settled principles.

Therefore, after keeping in mind all the aspects of International as well as national law, we can say that on the one hand, states are obliged to take effective measures to prevent terrorism, and on the other, to respect and protect the human rights of all the human beings including the accused persons in conformity with the principles of International as well as national law of the land 70 .

Key principles have been mentioned in international human rights as well as international humanitarian law instruments, and the violation of the principles of

70 Leiden Policy Recommendations on Counter-terrorism and International Law Nico Schrijver and Larissa van den Herik 1 April 2010 The Use of Force against Terrorists. international as well as national law principles should be condemned and the rights including that of suspects of terrorism and accused persons should be protected in conformity of these principles, because the human rights are the rights of people who possess the same by having a simple characteristic of human being and the accused persons also possess the same. Therefore, human rights are also available for all the people, including terrorists, suspects and the accused persons as well.

\section{REFERENCES}

[1] Office of the United Nations High Commissioner for Human Rights Human Rights, Terrorism and Counter-terrorism Fact Sheet No.32,http://www.ohchr.org/Documents/Publications/ Factsheet32EN.pdf, accessed on 10-09-2011.

[2] International Humanitarian Law and International Human Rights Law: Similarities and

differences,http://www.ehl.icrc.org/images/resources/pdf/ihl _and_ihrl.pdf, accessed on 10-09-2011.

[3] Counter-Terrorism Policy and Human Rights: Terrorism Bill and related matters, House of Lords House of Commons Joint Committee on Human Rights, Third Report of Session 200506.

[4] International Terrorism and Security Research, http://www.terrorism-research.com/, accessed on 10-09-201 1.

[5] Talking about Terrorism - Risks and Choices for Human Rights Organizations 2008 International Council on Human Rights Policy,

http://www.ichrp.org/files/reports/35/129_report_en.pdf

[6] Wilder Tayler, Notes on the Human Rights Movement and the Issue of Terrorism, International Council on Human Rights Policy, 2005,http://www.ichrp.org/files/papers/78/12 9 - Notes on the Human Rights Movement and the Iss ue_of_Terrorism_Tayler_Wilder_2005.pdf, accessed on 25-09-2011.

[7] Mark Gibney, Katarina Tomaševski, Jens Vedsted-Hansen, Transnational State Responsibility for Violations of Human Rights, Harvard Human Rights Journal, http://www.law.harvard.edu/students/orgs/hrj/iss12/gibney.s html, accessed on 13-09-2011.

[8] Terrorism and international law: Challenges and responses, http://www.iihl.org/iihl/Album/terrorism-law.pdf, accessed on 25-09-2011.

[9] Derogation from human rights treaties in situations of emergency, Rule of law in Armed Conflicts, Project, http://www.adhgeneva.ch/RULAC/derogation_from_human rights_treaties_in_situations_of_emergency.php, accessed on $02-\overline{10}-2011$.

[10] Emilie Marie Hafner-Burton, Laurence R. Helfer , Christopher J. Fariss, Emergency and Escape: Explaining Derogation from Human Rights Treaties,http://papers.ssrn.com/sol3/papers.cfm?abstract_id= 1622732, accessed on 10-10-2011. 
[11] Wilson John and P.V. Ramana, Terrorism and Human Rights, http://www.observerindia.com/cms/export/orfonline/module s/policybrief/attachments/trs_1171547246121.pdf, accessed on 10-10-2011.

[12] Torture, Inhuman or Degrading Treatment, http://www.hrea.org/index.php?doc id $=265$, accessed on 10-10-2011.

[13] Wilson John and P.V. Ramana, Terrorism and Human Rights, ORF policy brief, February 2007.

[14] Amy Zalman, Human Rights \& Terrorism: An Overview Expanding anti-terror measures produces new human rights issues,http://terrorism.about.com/od/humanrights/a/Human Rights.htm

[15] Talking about Terrorism - Risks and Choices for Human Rights Organisations, International Council on Human Rights Policy,

(2008),http://www.ichrp.org/files/reports/35/129_report_en. pdf, accessed on 24-09-2011.

[16] General Comment No. 18: Non-discrimination : . 11/10/1989.

[17] CCPR General Comment No. 18. (General Comments), http://www.unhchr.ch/tbs/doc.nsf/0/3888b0541f8501c9c125 63ed004b8d0e? Opendocument, accessed on 12-10-2011.

[18] Human Rights Watch: Suicide bombers 'war criminals', accessed on 12-10-2011.

[19] Accountability for US counter-terrorism human rights violations

[20] The Berlin Declaration, The ICJ Declaration on Upholding
Human Rights and the Rule of Law in Combating Terrorism Adopted 28 August 2004

[21] August 2008 Combating Terrorism under Human Rights and Humanitarian Law Regime Dr. Borhan Uddin Khan, Muhammad Mahbubur Rahman

[22] CRS Report for Congress Received through the CRS Web Order Code RL31367 Treatment of "Battlefield Detainees" in the War on Terrorism Updated November 15, 2005.

[23] Euro-Mediterranean Seminar Counter-terrorism and human rights Prague (16-17 June)http://www.consilium.europa.eu/ uedocs/cmsUpload/speech-Counter-terrorism_and_human_ri ghts_GdK_june_08_rev.pdf

[24] Protecting human Rights While Countering Terrorism, http://www.un.org/en/sc/ctc/rights.html

[25] Y.P. Chhibbar, Terrorism and Human Rights: National and International Perspective, PUCL Bulletin, 2003, http://www.pucl.org/Topics/Human-rights/2003/terrorism.ht $\mathrm{m}$

[26] Terrorism And Human Rights: Role Of The Security Personnel And The

Police,http://www.legalserviceindia.com/article/1271-Terrori sm-And-Human-Rights.html

[27] Lellie Ortega, Anti-terrorist laws in Pakistan, http://www.india-seminar.com/2002/512/512\%20kellie\%20o rtega.htm, accessed on 20-10-2011.

[28] Leiden Policy Recommendations on Counter-terrorism and International Law Nico Schrijver and Larissa van den Herik 1 April 2010 The Use of Force against Terrorists. 